\title{
Evaluation of Using V-Class (Moodle) in Faculty of Teacher Training and Education Universitas Lampung During Work from Home
}

\author{
Bayu Saputra \\ Pendidikan Kimia \\ Universitas Lampung \\ Lampung, Indonesia \\ bayu.saputra1988@fkip.unila.ac.id
}

\author{
Fanni Rahmawati \\ Pendidikan Ekonomi \\ Universitas Lampung \\ Lampung, Indonesia \\ fanni.rahmawati93@fkip.unila.ac.id
}

\begin{abstract}
This study aims to obtain an overview of student learning outcomes, describe activities and learning barriers using Class at FKIP Unila during working from home. This evaluation process includes the availability of technological support, competence in using the V-Class for learning at FKIP Unila. Methods: The method used in this research is a descriptive qualitative, interview, assisted with the calculation of questionnaires as an evaluation of facts in the field about lectures using V-Class at FKIP Unila during the work from home. The instruments used in this study were observation sheets, questions used to obtain information from respondents, in-depth interviews: Student learning outcomes while using V-Class showed excellent learning outcomes and were able to increase student learning independence. Learning activities using V-Class went well between lecturers and students.
\end{abstract}

Keywords-V-Class Evaluation, Unila FKIP, Work from Home Period

\section{INTRODUCTION}

21st-century learning enters the era of global competition according to the mandate of Law no. 20 of 2003 [1] the quality of education in Indonesia must improve from time to time accompanied by the readiness of teachers and students. Learning that has begun to be applied about the integration of online learning must be familiar, including using the software. As the director of the development of education is getting better in Indonesia, along with the covid-19 pandemic condition which has claimed many victims around the world. The affected education sector in Indonesia resulted in the closure of schools and learning was carried out from their respective homes. Coronavirus, which stands for Corona Virus Disease 2019, was first spread in China at the end of 2019 and entered Indonesia in March 2020. During this pandemic, the education sector forced policies in
Indonesia to implement Work From Home (WFH) learning. . This was done as an effort to prevent the spread of the COVID-19 virus. Changes in learning must occur and be carried out properly when face-toface becomes online learning. Online learning is done by utilizing information and communication technology. Online learning can also be said to be learning with e-learning.

E-learning is used with the help of systematic electronic devices [2]. According to Yidliz [3], eLearning is an innovative distance learning that provides a flexible, alternative impact, according to the needs of learning in the 21 st century. With e-Learning, learning does not have to be face-to-face or face-toface, but from each other's homes. The advantage of learning with e-Learning is that we can access learning anywhere, anytime [4]. Meanwhile, Rijal \& Sofiarini, [5] e-learning-based learning correlates with increasing motivation and learning outcomes. e-Learning is also a modern learning activity using the help of the internet [6]. The application of e-Learning in the learning process can use a learning application called Moodle. Moodle is a learning management system that can be used for free and has many features to support the learning process. Learning Management System or LMS has been widely used in almost all universities in Indonesia. According to Surjono [7], LMS is software or software that has multimedia resources in terms of delivering material online. The LMS used in learning can be in the form of Moodle which can be modified the installation process and its features according to distance learning. LMS Moodle or Modular ObjectOriented Dynamic Learning Environment can be accessed with a computer or smartphone with the help of the internet [8] This application is widely used by Indonesia because it can be modified by users to suit learning [9]. 
The features in using Moodle are available in the form of material uploads, assignments, discussions, quizzes including direct research. Lecturers or educators can carry out these activities and include controlling the time and number of meetings desired. Students or students can follow after being given access such as a join code in certain courses. The Moodle application is indeed widely used in several institutions, including the University of Lampung. The policy of the University of Lampung is to implement Work from Home learning by using the Moodle facilities developed at the ICT Center.

A learning system that is used fully during Work from Home for the first time at the University of Lampung, so it is very important to see the development of the readiness of human resources and supporting infrastructure. The learning system that changed from face-to-face to online learning certainly has an impact on change, both for students and lecturers. The Faculty of Teacher Training and Education, University of Lampung, (FKIP Unila) uses Moodle as a lesson as well as an object in this research. This online learning with Moodle has been developed at the University of Lampung and is given the name V-Class or Virtual Class. Previously, FKIP also developed a moodle under the name Edusmart and was carried out to accommodate special learning at FKIP Unila. However, for reasons of ease of reporting and shared perceptions, learning is carried out using V-Class during Work From Home [10].

Based on several existing studies, online learning can have a positive impact on improving the quality of learning. By looking at the developments taking place in higher education institutions abroad and at home, online learning, which previously started with blended learning, is widely used as a 'distance' learning system.

On a broader scale, online learning or online learning strongly supports the nature of lifelong learning. Related to this, to get effective online learning, its development requires in-depth study and trials, careful evaluation. The study that will be explored in this study is about evaluating learning using V-Class at FKIP Unila during the Work from Home Period. At this initial stage, the study will only focus on evaluating online learning at FKIP Unila by using VClass learning during Work From Home. This research contains a study of psychological, communication, technical aspects, the impact on learning achievement, new assessment methods, collaborative learning methods, and so on to improve an effective and quality learning system. An effective and quality learning process, namely learning that can create a high sense of curiosity and independent learning activities (learning independence), certainly makes it easier to achieve learning objectives [11].

\section{METHOD}

This study uses a qualitative descriptive method, to evaluate the facts that occurred in the lecture process with V-Class at FKIP Unila during the online WFH period. Describe the courses implemented by online learning, the variety of learning activities provided in each course, the profile of learning outcomes, the responses of the course tutors and students. The several stages carried out are as follows; Evaluation of internet network and selection of open-access software (open source); Evaluation of installation, server settings, and program settings for users. Evaluation of the implementation of V-Class online lectures during the WFH period; Evaluation of the implementation of $\mathrm{V}$ Class online lectures during the WFH period. The data in this development research were obtained through observation, interview questionnaires, and documentation data. User response questionnaire instruments and supporting data are used to collect data on the level of attractiveness, convenience, and usefulness; and test result data is used to determine the effectiveness of online learning.

\section{RESULT AND DISCUSSION}

Hasil dari penelitian ini berfokus pada evaluasi terhadap pengunaan $\mathrm{V}$-Class dalam pembelajaran pada masa Work From Home. Evaluasi kegiatan perkuliahan ini dilaksanakan di FKIP Universitas Lampung baik dengan Dosen, mahasiswa serta heldesk pengembang perkuliahan V-Class. Kegiatan perkuliahan ini mampu meningkatkan kualitas pembelajaran serta menciptakan lingkungan belajar yang fleksibel, mudah diakses dari mana saja dan kapan saja. Dosen dan mahasiswa dapat mengikuti proses belajar, berdiskusi dan ujian online secara mandiri serta mampu meningkatkan motivasi belajar mahasiswa untuk berpikir tingkat tinggi. Teknik pengumpulan data yang digunakan berupa lembar wawancara dosen, mahasiswa serta heldesk pengembang perkuliahan V-Class yang didistribusikan melalui google form

\section{A. The ability of students and lecturers to use the $V$ - Class for learning at FKIP UNILA during the work from home period}

First, the ability of students and lecturers to use the $\mathrm{V}$-Class for learning, based on the results of the questionnaire analysis conducted on students in Table 1 with indicators of contribution to learning, the average answer obtained was $63.8 \%$ stating very well, $24 \%$ good, $10.8 \%$ is sufficient and $1.4 \%$ is not good. Furthermore, on indicators of teacher or lecturer skills and response accuracy, the average answers obtained were $78.7 \%$ stating very well, $16.2 \%$ good, $3.8 \%$ enough and $2.7 \%$ not good. Then the indicator of the lecture content on the V-Class, the average answer obtained is $77 \%$ stating very good, $17.5 \%$ good, and $5.5 \%$ enough.

The results of the questionnaire analysis showed that both students and lecturers were able to use the V- 
class very well. This can also be seen from the results of student questionnaires in Table 1, the contribution indicators in learning the 2nd statement point the knowledge skill level at the beginning of learning show a percentage of $44 \%$ very good and in the 3 rd statement point, the knowledge skill level at the end of the lesson shows $80 \%$ very well as can be seen in Figure 1.

Based on the data from the analysis of student questionnaires on the contribution to learning using $\mathrm{V}$ Class, most of the students showed a very good level of change in knowledge at the end of learning compared to at the beginning of learning. This indicates that the technology and information capabilities possessed by students can lead students to use and utilize V-Class in the implementation of online learning so that it has an impact on improving learning outcomes. As stated by Husain [12], that to increase the effectiveness of the learning process that can improve activities and learning outcomes, the use of information and communication technology in learning plays an important role as a liaison in the implementation of knowledge transfer. Utami [13] also revealed that the development of information and communication technology in education opens up opportunities to create student-centered learning by utilizing technology (internet) through e-learning to create fun learning and have an impact on increasing student learning activities.

The results of this questionnaire are supported by the results of student interviews, based on the results of interviews, students said that they experienced an increase in learning outcomes and felt at ease with the V-Class as an intermediary for online lectures during this pandemic. As shown in the following respondent statements:

"The improvement in my learning outcomes is quite good after the V-Class-based learning. My learning outcomes have increased by using V-Class because assignments and exercises can be well organized so that it makes it easier for students to see the progress of learning outcomes."

This increase in learning outcomes is due to the perceived ease of learning using V-Class, such as the ease of accessing learning videos, accessing wellorganized courses. As shown in Figure 2.

In addition to a well-organized list of courses, students can also download materials at any time not limited by time. Videos from online meetings can be viewed again. Flexible V-Class access can be used via PC, tablet, or smartphone. This is in line with Y1ldiz et al [3] which states that E-learning is an online learning system that is carried out using assistive devices. Innovative synchronous distance learning tools provide alternative, flexible and opportunity-rich learning, which is highly suited to the demands and needs of 21 stcentury learners. Sofyana \& Rozaq [14] added that online learning is not limited by space and time, and does not require students to always study in rigid classrooms and rules. Likewise with Hameed, Baidii \& Cullen [15]; Akkoyunlu \& Soylu [16] added that in online learning the material can be accessed anywhere, anytime, and as often as possible if something is forgotten.

Likewise, the results of interviews that have been conducted with lecturers, said that student learning outcomes showed very good results, followed by student independence which developed very well. In addition, the interaction of students and lecturers went well, and was active in learning activities even though lectures were carried out online through the Unila VClass LMS. This is in line with Sowiyah [17] through his research revealing that using online forums in learning has a positive impact and gets a good response from lecturers and students. Students and lecturers are actively involved in learning activities. Online learning can make students learn independently and can increase Sadikin \& Hamidah's motivation [18]. Online learning requires students to be independent in cultivating knowledge within themselves. Independence is the behavior of individuals who can overcome obstacles or problems, can have self-confidence, take initiative, and do not depend on others. This will be a positive influence for students [18-20]. The use of the V-Class LMS can be an alternative solution to increase student learning independence in online learning during the Covid-19 pandemic. This is supported by Yulistia, Fitria \& Anggraini [22] who revealed that the V-Class LMS can increase student learning independence.

The ability of students to use the V-Class so that it has an impact on improving learning outcomes certainly cannot be separated from the intervention of the lecturer. The ability of lecturers to use the V-Class to carry out their obligations as educational practitioners during this pandemic has shown very good results. This can be seen in Table 1, from the results of student questionnaires on teaching skills and response accuracy, the percentage of $78.7 \%$ is very good, then the results of the lecture content given by lecturers in $\mathrm{V}$-Class show a very good percentage of $77 \%$. As seen in Figure 3.

Based on the data from the questionnaire analysis, it can be seen that the lecturers have excellent abilities in skill indicators and response accuracy which includes learning effectiveness, delivering clear and structured presentations. Then the lecturer is very good in terms of providing important information to students as well as reading, providing answers to questions given by students and useful input. Furthermore, the results of the questionnaire on indicators of lecture content in the V-Class which include clear learning objectives, appropriate learning task loads, good learning arrangements so that students are able to participate fully and well-planned learning content preparation show a very good percentage of results. As according to $\mathrm{Hu} \&$ Gramling [23] revealed that setting learning goals, time management and good cognitive strategies 
can help students achieve good learning outcomes in online learning. Kusni [24] added that educators must be able to prepare materials and digital references that students can refer to. Educators who are able to prepare materials and use e-learning, then the implementation of learning will run well even though it is carried out online. Likewise, according to Fahmi, Syaiful, \& Soffi [25] who explained that the mastery of e-learning by an educational practitioner is a key in the implementation of e-learning activities and plays an important role as a medium for creating effective, efficient learning and enhancing the quality of learning. Likewise, Haag [26] explains that implementing e-learning in learning can improve the quality of learning and increase teacher professionalism in teaching.

The results of this questionnaire are supported by the results of student interviews, based on the results of student interviews revealing the teaching system carried out by the lecturers is very good, effective, efficient, and interesting. Interesting in this case because on the V-Class platform, lecturers can add, ppt, video, or in other forms. As shown in the following respondent's statement:

"In my opinion, the teaching system carried out by lecturers through the V-Class-based lecture system is very effective, efficient, and of course fun, through the $V$-Class you can access the Google meet link for virtual face-to-face lectures, material in the form of text and videos that support learning can also be accessed via V-Class."

The addition of interactive videos in learning helps students understand the material and increases interest in learning activities because the delivery of learning materials is not only in the form of theories. A welldesigned interactive video can help facilitate students to conclude a stage of the process [26]. Thus, one of the important points that lecturers need to prepare in learning is content, because in online learning content plays an important role [27]. This indicates that the ability of lecturers to use the V-Class for learning is very good so that it can increase students' enthusiasm for learning. Lecturers who can prepare content and manage the V-Class LMS well, then the implementation of online learning can run optimally.

Overall, the ability of students and lecturers to use the V-Class for learning at FKIP UNILA during the WFH period showed very good results. So that it provides convenience for lecturers and students in carrying out lectures and has an impact on the development of learning independence and improving student learning outcomes. This is in line with the research results of Yulistia, Fitri \& Anggraini [22]; Indrayana \& Sadikin [28] that the UNILA V-Class LMS can increase student learning independence, make it easier for students to attend lectures, and can prevent the transmission of covid-19 on campus.

\section{B. Activities and learning barriers for students and lecturers during the use of V-Class at FKIP UNILA during WFH}

Lecture activities during the Work From Home period using the V-Class went well. Based on the results of interviews conducted with lecturers, students, and helpdesk admins, overall it was revealed that online lecture activities based on V-Class have been going well. Based on the results of interviews with lecturers and students, they said that lecture activities went well whereas in lectures using V-Class for learning was easier in terms of discussion, attendance, and delivery of material, either in the form of files or in writing. In addition, to build good interactions in lecture activities, lecturers create discussion forums and ask questions through synchronized google meet, in addition to using variations in the use of synchronous and asynchronous systems or others. Students become more enthusiastic in lecture activities and the emergence of a sense of courage in discussions. Students become confident in arguing and giving their views and opinions scientifically. According to Yuberti [29], the implementation of learning in special conditions is guided by 8 principles. The seventh principle is the implementation of learning focused on mastery of competencies, student-centered learning to build selfconfidence and self-esteem. Discussion is a method that involves the interaction of all parties in the learning process. Currently, online discussion methods are commonly used in various communication application vehicles. Online discussion is a way of learning about a problem based on a website. Discussions can involve students giving suggestions or ideas.

Based on the results of the interview, the helpdesk admin said that the development of the V-Class LMS platform had been carried out with improvements to the features of the V-Class. Likewise, the readiness of the $\mathrm{V}$-Class learning platform during the WFH period was better than in the previous year. In line with this, based on the results of the interview, the lecturer revealed that the V-Class learning platform is now much better, has adequate equipment in managing online classes. Several additional features are already synchronized with Google Meet, attendance record facilities, and so on as well as making it easier to provide material. As shown in the following respondent statements:

"V-Class is now much better from year to year and the provision of $v$-Class makes it easier for lecturers to provide material, it is increasing and there are several additional features such as synchronization with google meet, attendance record facilities, etc."

The features presented can help students learn independently, collaboratively, and make students more active in learning. In addition, instructors can upload subject matter that can be downloaded by students, give assignments, provide quizzes, and there is a discussion forum so that online classes feel alive and students can easily learn material that has been and 
will be studied in learning. This indicates that learning activities through LMS V-Class are a commonly used method. Especially during the current Covid-19 emergency, it has demanded the adaptation of various parties to use online learning vehicles. This is in line with Lestari \& Hamka [30] who explained that online learning vehicles, one of which is the V-Class, which can overcome the limitations between lecturers and students in terms of time or certain conditions that do not allow learning to be carried out face-to-face in class.

However, behind the ability and convenience of lecturers and students during the use of V-Class at FKIP UNILA during the work from home period, there are several obstacles in the implementation of online learning through the V-Class LMS, both from students, lecturers, and helpdesk admins. Especially for students who are still new to online learning. Students are required to adapt faster to self-taught how to use the UNILA V-Class in learning during the work from the home period of the Covid-19 pandemic. This is in line with Lopes [31] revealing ...professors and students did not have established practices in using online tools so that the actual use of the LMS was not predictable. In addition, other obstacles expressed by students were obstacles in accessing the V-Class, often the server was down, causing delays in attendance even when collecting assignments and exams. Furthermore, the factor of using extravagant data packets and unsupported signals are the most common obstacles experienced by students, because not all students live in places that easily get access to a good internet network [32] As shown in the following respondent's statement:

"Weak signal constraints; Sometimes an error occurs in the system so that it is difficult to see the activity in V-Class; The system sometimes experiences errors, on a slow internet network so that V-Class cannot be opened.; Sometimes there are problems when absent, due to unsupported signals; The problem is that sometimes the web suddenly goes down when it is accessed so that lectures are also delayed."
Students revealed that they were not ready and motivated in participating in online learning. This arises because of the sudden change in the learning process to the point that it is required to be fully online due to the Covid-19 pandemic so that students feel the lack of direct social interaction with friends between students and lecturers which can lead to boredom and feeling isolated in their learning environment so that it will have an impact on decreased enthusiasm and motivation to learn to take part in online learning activities. [33]. Online learning is also an obstacle for practical courses. This is expressed by students that they feel the need to go to the field directly rather than just watching through the link provided by the lecturer. In line with this, the lecturer also revealed that there were several points that indeed the implementation of the V-Class for learning was not achieved, this was because there were courses that had to be practiced in the implementation of the lectures. Furthermore, another obstacle expressed by the lecturer was on the $\mathrm{V}$-Class learning platform, the teacher's account on the course was sometimes lost so that another teacher had to re-enroll. Furthermore, the helpdesk revealed that the perceived obstacle to the development of this V-Class LMS is that users still need education in the form of video documentation and manual books, because of limited human resources, this documentation is still in the process of being drafted. Another obstacle is the need for the development of a V-Class system that is integrated with the Siakadu and Remuneration system. In line with Sara \& Mude [34], the learning process will run well with the availability of facilities and infrastructure, then the learning outcomes that have been planned will be realized. Education providers in implementing E-learning need to prepare, among others, provide training to educators who will use it, prepare to host, prepare technicians or operators who understand this. For educators, they must be willing to learn to use it and be willing to prepare materials and supporting materials. Meanwhile, students need to prepare a computer/laptop/smartphone and be connected to a good internet network.

\section{Figures and Tables}

TABLE I. STUDENT QUESTIONNAIRE RESULTS ON THE USE OF V-CLASS FOR LEARNING

\begin{tabular}{|c|c|c|c|c|c|}
\hline \multirow{2}{*}{ Indicator } & \multirow{2}{*}{ Questions } & \multicolumn{4}{|c|}{ Percentage \% } \\
\hline & & $S B$ & $\boldsymbol{B}$ & $C$ & $T B$ \\
\hline \multirow{5}{*}{$\begin{array}{l}\text { Contribution to } \\
\text { learning }\end{array}$} & The level of effort you put into learning & 50 & 35 & 10 & 5 \\
\hline & Skill/knowledge level at the beginning of learning & 44 & 26 & 28 & 2 \\
\hline & Skill/knowledge level at the end of the lesson & 80 & 15 & 5 & 0 \\
\hline & Level of skill/knowledge required to complete this lesson & 75 & 20 & 5 & 0 \\
\hline & Contribution of learning to your skills/knowledge & 70 & 24 & 6 & 0 \\
\hline \multicolumn{2}{|r|}{ Average } & 63,8 & 24 & $\mathbf{1 0 , 8}$ & 1,4 \\
\hline \multirow{6}{*}{$\begin{array}{l}\text { Responsive skill } \\
\text { and accuracy }\end{array}$} & Instructors are effective teachers/practitioners & 87 & 10 & 3 & 0 \\
\hline & Presentation is clear and structured & 85 & 13 & 2 & 0 \\
\hline & The instructor stimulates the interest of the learning participants & 70 & 20 & 7 & 3 \\
\hline & Instructors use time effectively in class & 80 & 16 & 2 & 2 \\
\hline & Instructors are always there and helpful & 72 & 18 & 7 & 3 \\
\hline & Fast scoring and includes helpful feedback & 78 & 20 & 2 & 0 \\
\hline
\end{tabular}




\begin{tabular}{|c|c|c|c|c|c|}
\hline \multirow{2}{*}{ Indicator } & \multicolumn{1}{c|}{ Questions } & \multicolumn{3}{c|}{ Percentage $\%$} \\
\cline { 3 - 6 } & \multicolumn{1}{|c|}{ Average } & $\boldsymbol{S B}$ & $\boldsymbol{B}$ & $\boldsymbol{C}$ & $\boldsymbol{T B}$ \\
\hline \multirow{3}{*}{$\begin{array}{l}\text { Course content in } \\
\text { V-Class }\end{array}$} & Clear learning objectives & $\mathbf{7 8 , 7}$ & $\mathbf{1 6 , 2}$ & $\mathbf{3 , 8}$ & $\mathbf{2 , 7}$ \\
\cline { 3 - 6 } & Learning content is well structured and planned & 88 & 10 & 2 & 0 \\
\cline { 2 - 6 } & Appropriate learning task load & 77 & 18 & 5 & 0 \\
\cline { 2 - 6 } & Learning is structured to allow all students to participate fully & 70 & 25 & 5 & 0 \\
\hline \multicolumn{2}{|c|}{ Average } & $\mathbf{7 7 , 0}$ & $\mathbf{1 7 , 5}$ & $\mathbf{5 , 5}$ & 0 \\
\hline
\end{tabular}

TABLE II. SUMMARY OF LECTURERS INTERVIEW ON THE USE OF V-CLASS FOR LEARNING

\begin{tabular}{|c|c|}
\hline Indicator & Respondent's Answer \\
\hline $\begin{array}{l}\text { V-Class-based online lecture system } \\
\text { activities in taught courses }\end{array}$ & $\begin{array}{l}V \text {-Class can facilitate online learning well. It is very helpful to use V-Class in } \\
\text { lectures, makes it easier to deliver material in the form of files or writings, } \\
\text { assign assignments and enter exam questions as well as determine the time for } \\
\text { exams, attendance, and discussions. Lectures run smoothly but are unable to } \\
\text { monitor the course of independent practicum. }\end{array}$ \\
\hline $\begin{array}{l}\text { Interaction in the V-Class-based lecture } \\
\text { learning process }\end{array}$ & $\begin{array}{l}\text { Delivering learning objectives, managing learning time, and appropriate } \\
\text { cognitive strategies. Create discussion forums and ask questions through } \\
\text { google meet. Using variations of the use of synchronous \& asynchronous } \\
\text { systems (Zoom, etc.) tells students to be required to discuss material and } \\
\text { attendance after or when the lecture schedule starts. complete learning } \\
\text { indicators at each meeting, complete the material with various teaching } \\
\text { materials (material files, learning videos uploaded on YouTube, and light } \\
\text { quizzes that refresh the material) }\end{array}$ \\
\hline $\begin{array}{l}\text { Student enthusiasm for V-Class-based } \\
\text { lectures }\end{array}$ & $\begin{array}{l}\text { The enthusiasm of students is very good because it is very helpful for students } \\
\text { to get lecture material. quite high in terms of response and task execution }\end{array}$ \\
\hline $\begin{array}{l}\text { The ability of learning outcomes that } \\
\text { arise and develop for students }\end{array}$ & $\begin{array}{l}\text { Independent learning and self-regulation are well developed, ICT literacy is } \\
\text { the main ability. Learning outcomes are very good, through the implementation } \\
\text { of V-Class-based lectures, students are better trained from the affective aspect } \\
\text { (discipline, responsibility, etc.). Learning outcomes are good while online } \\
\text { using V-Class, but there are some points that indeed the implementation of V- } \\
\text { Class is not achieved because there are courses that must be practiced in } \\
\text { lectures }\end{array}$ \\
\hline $\begin{array}{l}\text { The effectiveness of the V-Class-based } \\
\text { lecture system, during the Work From the } \\
\text { Home period }\end{array}$ & $\begin{array}{l}\text { The V-Class-based lecture system, during the Work From the Home period, is } \\
\text { very effectively implemented and can be an alternative solution to increase } \\
\text { student learning independence in online learning during the Covid-19 } \\
\text { pandemic. Much more effective than before because of all the full features }\end{array}$ \\
\hline $\begin{array}{l}\text { Readiness of the V-Class learning } \\
\text { platform from }\end{array}$ & $\begin{array}{l}V \text {-Class is now much better. However, sometimes the teacher's account on the } \\
\text { course is lost so that it has to be re-enrolled by another teacher. quite good } \\
\text { and updates from year to year and the provision of V-Class makes it easier for } \\
\text { lecturers to provide material. Increasingly, there are several additional } \\
\text { features, such as synchronization with Google Meet, attendance record } \\
\text { facilities, etc }\end{array}$ \\
\hline $\begin{array}{l}\text { Technical service for using V-Class } \\
\text { during WFH }\end{array}$ & V-Clas. \\
\hline
\end{tabular}

TABLE III. SUMMARY OF STUDENT INTERVIEWS ON THE USE OF V-CLASS FOR LEARNING

\begin{tabular}{|c|c|}
\hline Indicator & Respondent's Answer \\
\hline $\begin{array}{l}\text { Kegiatan sistem perkuliahan berbasis V- } \\
\text { Class }\end{array}$ & $\begin{array}{l}\text { - So far, V-Class-based online learning has been quite effective, with V- } \\
\text { Class being able to help this online learning. However, the togetherness } \\
\text { offace-to-face lectures cannot be replaced through online learning } \\
\text { - So far, I am not ready to participate in online learning, because I cannot } \\
\text { meet in person so I am less enthusiastic and motivated in learning. } \\
\text { In my opinion, V-Class-based online lecture system activities are very } \\
\text { good and very helpful for face-to-face lectures during a pandemic like } \\
\text { today. } \\
\text { In my opinion, the online lecture system activities based on V-Class have } \\
\text { been going well, especially after V-Class was upgraded the system is } \\
\text { easier for students to use, learning materials are much easier to access } \\
\text { either in pdfor video } \\
\text { In my opinion, online learning activities based on V-Class have been going } \\
\text { well, the learning materials provided by the lecturers can be accessed } \\
\text { easily through V-Class. } \\
\text { In my opinion, it is very effective because V-Class is easy to access on both } \\
\text { cellphones and laptops } \\
\text { The activities of the online lecture system are directed and systematic but } \\
\text { reduce the sense of togetherness with friends, }\end{array}$ \\
\hline
\end{tabular}




\begin{tabular}{|c|c|}
\hline Indicator & Respondent's Answer \\
\hline $\begin{array}{l}\text { The teaching system carried out by } \\
\text { lecturers is through a V-Class-based } \\
\text { lecture system. }\end{array}$ & $\begin{array}{l}\text { - Materials and assignments are given through V-Class, so students just } \\
\text { have to see all the activities that have been provided by the lecturer, both } \\
\text { material and assignments } \\
\text { In my opinion, the teaching system carried out by lecturers through the V- } \\
\text { Class-based lecture system is very effective, efficient, and of course fun } \\
\text { In my opinion, the teaching given by the lecturers through the V-Class is } \\
\text { also good, through the V-Class the Google meet link can be accessed to } \\
\text { meet virtually in lectures, the material in the form of text and videos can } \\
\text { also be accessed through the V-Class. } \\
\text { Very good, especially in V-Class, teaching materials and learning models } \\
\text { have been included, both videos that support learning } \\
\text { - Iam happy if mylecturers use V-Class because in V-Class they can include } \\
\text { various materials, both written and video } \\
\text { The teaching system carried out by lecturers through a V-Class-based } \\
\text { lecture system makes it easier for students, moreover there is a discussion } \\
\text { forum to discuss a problem so that students can actively participate } \\
\text { virtually through V-Class }\end{array}$ \\
\hline $\begin{array}{l}\text { Improve your learning outcomes after } \\
\text { implementing V-Class-based lectures. }\end{array}$ & $\begin{array}{l}\text { - } \quad \text { Quite improved, from previous learning } \\
\text { - There is progress because this is the second semester using V-Class so I'm } \\
\text { getting used to it. } \\
\text { - So far my study results have improved quite a bit but there are some } \\
\text { problems with internet network access during quizzes or exams. } \\
\text { The improvement in my learning outcomes is quite good after V-Class- } \\
\text { based learning. The improvement of my learning outcomes increased by } \\
\text { using V-Class, because the tasks and exercises can be well organized so } \\
\text { that it can make it easier for students to see the progress of learning } \\
\text { outcomes. }\end{array}$ \\
\hline $\begin{array}{l}\text { Constraints felt against the V-Class- } \\
\text { based lecture system }\end{array}$ & $\begin{array}{l}\text { - } \\
\text { - } \quad \text { Occasional errors, and weak signal problems } \\
\text { - } \quad \text { Sometimes an error occurs in the system so that it is difficult to see the } \\
\text { activity in V-Class } \\
\text { - There are no problems, it's just that the signal in my area sometimes seems } \\
\text { to be lost. } \\
\text { - The system sometimes experiences errors, on a slow internet network, V- } \\
\text { Class cannot be opened. } \\
\text { - Sometimes there are problems when absent, due to unsupported signals } \\
\text { The problem is that sometimes the web suddenly goes down when it is } \\
\text { accessed so that lectures are also delayed. }\end{array}$ \\
\hline $\begin{array}{l}\text { The perceived convenience of the V- } \\
\text { Class-based lecture system }\end{array}$ & $\begin{array}{l}\text { - The convenience that I feel is accessing learning videos, Google meet } \\
\text { links, and downloading materials that can be downloaded at any time } \\
\text { without a time limit. } \\
\text { - It's easier if the network is smooth and V-Class is not down, we can } \\
\text { download the files that we have sent the assignment to again, and it's quite } \\
\text { helpful to remember the previous material and can be accessed anytime } \\
\text { and anywhere } \\
\text { I can get or download the material provided easily and the discussion } \\
\text { media is quite effective for students. } \\
\text { The convenience I feel is the ease of accessing courses that are neatly } \\
\text { arranged, the presence feature is located above so you don't need to scroll } \\
\text { too far, the task collection forum is organized so that it makes it easier for } \\
\text { students to collect assignments, and the DiV-Class also has a place for } \\
\text { lecture materials so that students are easy to access the material and } \\
\text { download it anytime not limited by time }\end{array}$ \\
\hline $\begin{array}{l}\text { The readiness of the V-Class learning } \\
\text { platform from year to year compared to } \\
\text { the Work From the Home period }\end{array}$ & $\begin{array}{l}\text { - The V-Class learning platform is getting better and more interesting. } \\
\text { - The current V-Class has been updated, especially in the presence and } \\
\text { collection of assignments or exams features. Attendance which used to be } \\
\text { done at any time is now limited in time to improve student discipline. So } \\
\text { that the readiness of the V-Class platform in my opinion increases from } \\
\text { year to year. } \\
\text { The current V-Class is even more organized for time, so if the lecturer } \\
\text { makes us absent as students, we can only be absent according to the time } \\
\text { that the lecturer has set } \\
\text { From year to year continues to experience changes that are more } \\
\text { effective and at this time V-Class is getting more effective and better than } \\
\text { the previous version, it is better than the previous version. } \\
\text {-Class which is now much more ready, especially its readiness can be } \\
\text { seen in the presence feature }\end{array}$ \\
\hline
\end{tabular}




\begin{tabular}{|c|c|}
\hline Indicator & Respondent's Answer \\
\hline $\begin{array}{l}\text { Technical service on using V-Class } \\
\text { during WFH }\end{array}$ & - V-Class technical service during WFH is very good \\
\hline
\end{tabular}

TABLE IV. SUMMARY OF HELPDESK INTERVIEWS ON USING V-CLASS FOR LEARNING

\begin{tabular}{|l|l|}
\hline \multicolumn{1}{|c|}{ Indicator } & \multicolumn{1}{|c|}{ Respondent's Answer } \\
\hline $\begin{array}{l}\text { V-Class-based online lecture system } \\
\text { activities }\end{array}$ & $\begin{array}{l}\text { Overall, the V-Class-based online lecture system activities are } \\
\text { going well }\end{array}$ \\
\hline $\begin{array}{l}\text { Development of the V-Class LMS platform } \\
\text { for lectures }\end{array}$ & $\begin{array}{l}\text { Improvements have been made to the features in V-Class and } \\
\text { can facilitate learning }\end{array}$ \\
\hline $\begin{array}{l}\text { Obstacles to V-Class LMS development } \\
\text { with users. }\end{array}$ & $\begin{array}{l}\text { Requires special skills in making materials. Users still need } \\
\text { education in the form of video documentation and manual } \\
\text { books, because of limited human resources, this documentation } \\
\text { is still in the process of being drafted. }\end{array}$ \\
\hline $\begin{array}{l}\text { The readiness of the V-Class learning } \\
\text { platform from year to year compared to the } \\
\text { Work From the Home period }\end{array}$ & $\begin{array}{l}\text { During the work from home period, it was better than the } \\
\text { previous few years. }\end{array}$ \\
\hline $\begin{array}{l}\text { Technical service on using V-Class during } \\
\text { WFH }\end{array}$ & $\begin{array}{l}\text { It's still running, as usual, there are discussions via email, WA, } \\
\text { all services are done 100\% online. }\end{array}$ \\
\hline
\end{tabular}

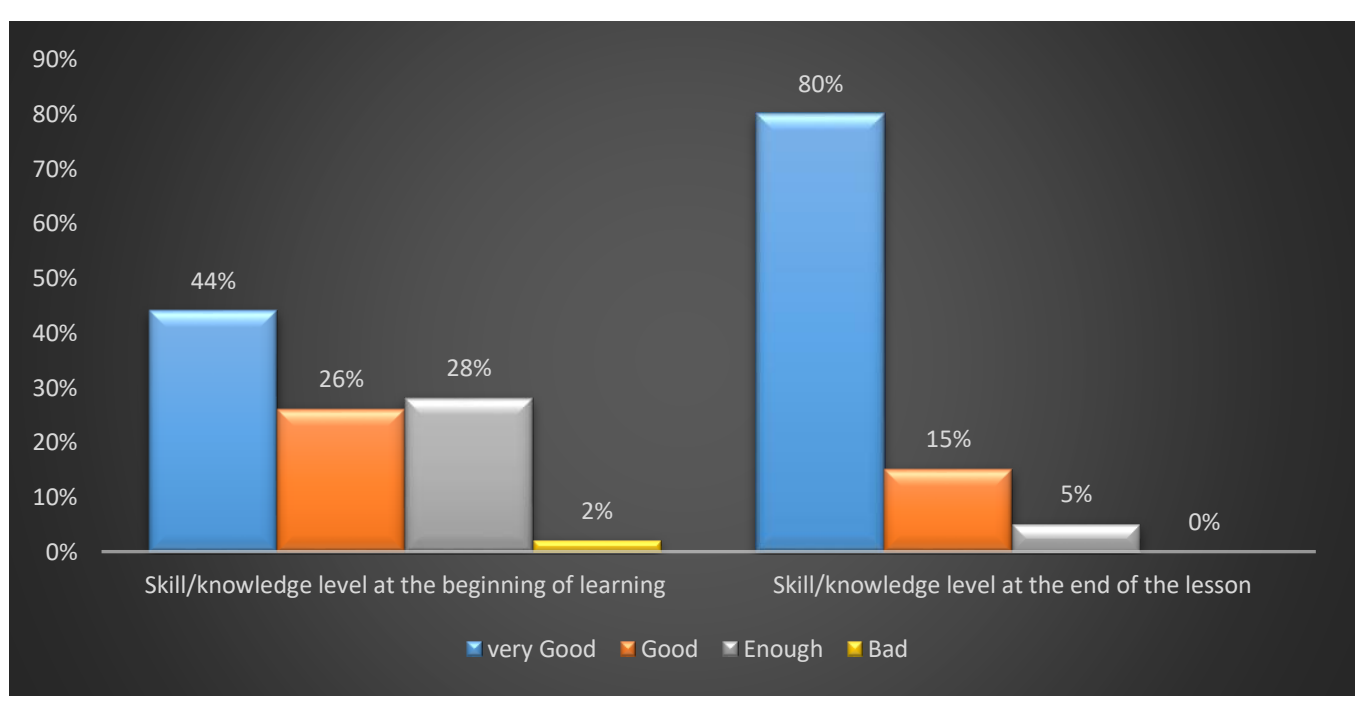

Fig. 1. Student responses to contributions in learning using V-Class 


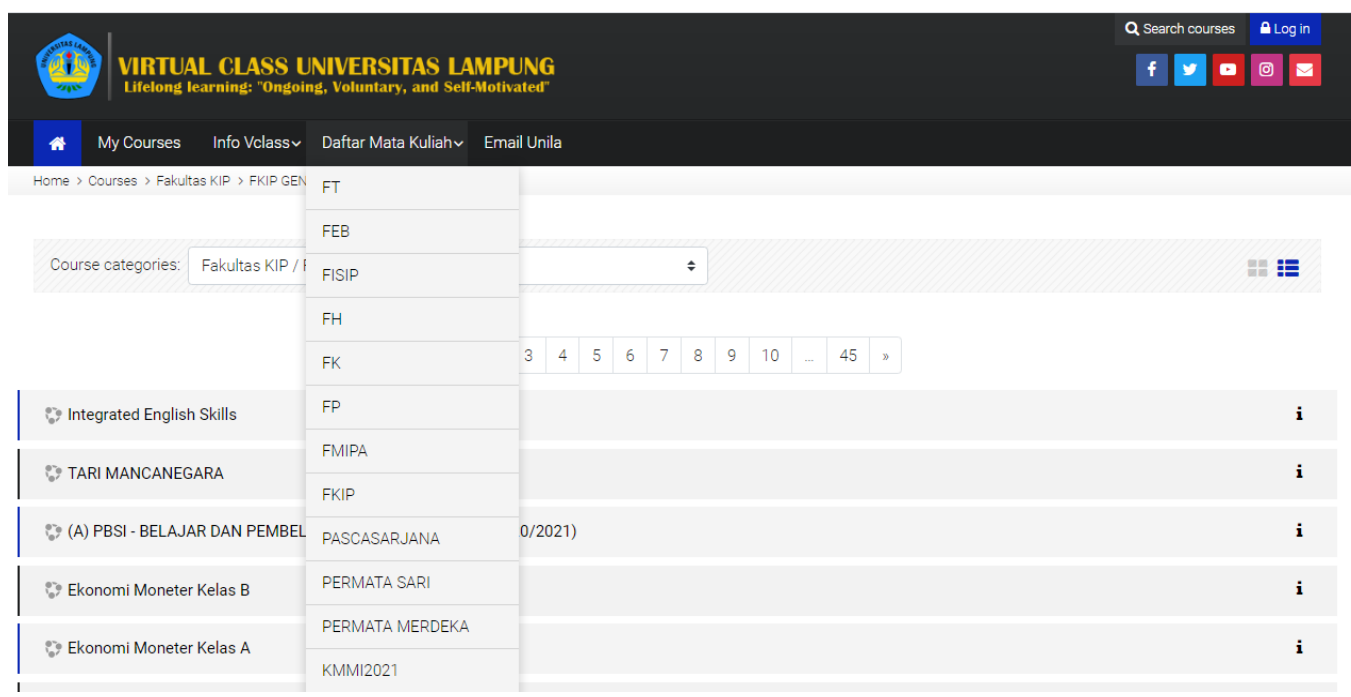

Fig. 2. Lampung University Virtual Class Display using V-Class

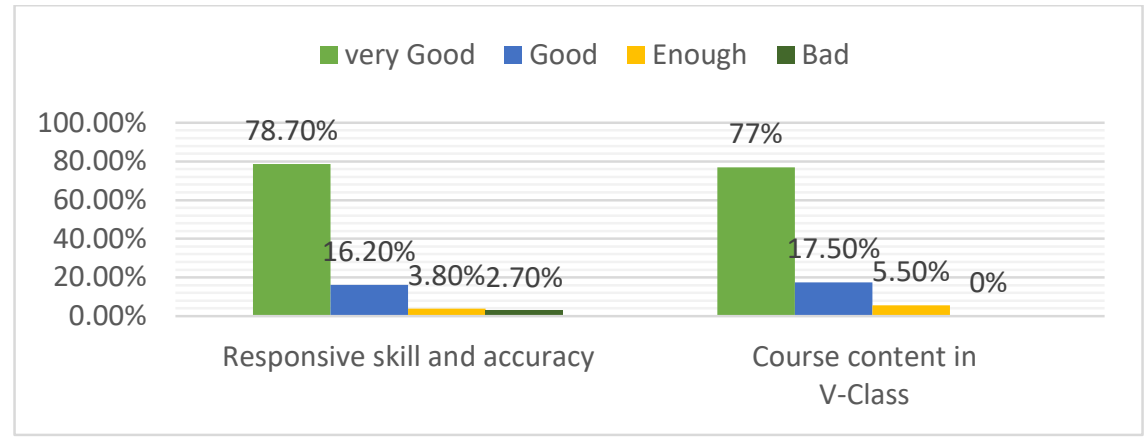

Fig. 3. Student response to the teacher's skills and the accuracy of responding as well as lecture content in V-Class

\section{CONCLUSION}

Based on the results of data analysis and discussions that have been stated previously, it can be concluded that the profile of student learning outcomes while using the V-Class during the work from the home period shows excellent learning outcomes and can increase student learning independence. Likewise, learning activities using V-Class run well between lecturers and students.

\section{ACKNOWLEDGMENT}

A big thank you to the Rector of the Universitas Lampung through the Institute for Research and Community Service (LPPM) for funding this research. Thanks also to the dean of FKIP Unila, and all the teams who helped in the completion of this research.

\section{REFERENCES}

[1] UU No 20 Tahun 2003 Tentang Sistem Pendidikan Nasional

[2] Rusman, Kurniawan, D., \& Riyana, C. (2012). Pembelajaran Berbasis Teknologi Informasi dan Komunikasi (2nd ed.). PT. RAJAGRAFINDO PERSADA

[3] Yıldız, E., Sarıtaş, M. T., \& Can ŞENEL, H. (2015). Examining the Attitudes and Intention to Use Synchronous Distance Learning Technology among Preservice Teachers: A
Qualitative Perspective of Technology Acceptance Model. American Journal of Educational Research, 3(10A), 17-25. https://doi.org/10.12691/education-3-10a-3

[4] Maudiarti, S. (2018). Penerapan E-Learning Di Perguruan Tinggi. Perspektif Ilmu Pendidikan, 32(1), 51-66. https://doi.org/10.21009/pip.321.7

[5] Rijal, A., \& Sofiarini, A. (2019). Pengembangan E-Learning Mata Kuliah Pembelajaran Matematika Sd Berbasis Aplikasi Moodle Di Pgsd. Jurnal Basicedu, 3(4), 20712082. https://doi.org/10.31004/basicedu.v3i4.266

[6] Inggriyani, F., Fazriyah, N., \& Purbasari, A. (2019). Penggunaan E-learning Berbasis Moodle bagi KKG Sekolah Dasar di Kecamatan Lengkong Kota Bandung. Jurnal SOLMA, $8(2), 268$. https://doi.org/10.29405/solma.v8i2.3695

[7] Surjono, H. D. (2013). Membangun Course E - Learning Berbasis Moodle (2nded.). UNY. PRESS.

[8] Sari, P. A., \& Setiawan, A. (2018). The Development of Internet-Based Economic Learning Media using Moodle Approach. International Journal of Active Learning, 3(2), 100109. http://journal.unnes.ac.id/nju/index.php/ija

[9] Bariyah, S. H., \& Imania, K. A. N. (2018). Implementasi Blended Learning Berbasis Moodle Pada Jurusan Pendidikan Teknologi Informasi. Jurnal Petik, 4(2), 106- 113. https://doi.org/10.31980/jpetik.v4i2.10

[10] Unila.ac.id (February, 24 2021) diakses dari https://www.unila.ac.id/waspadacovid-19-unila-terapkanvirtual-class/

[11] Ismaniati, C., Sungkono, \& Dian, W. (2015). Model blended learning untuk meningkatkan kemandirian belajar dan daya 
Tarik dalam perkuliahan. Jurnal penelitian ilmu PendidikaN, $8(2), 19-27$

[12] Husain, C. (2014). Pemanfaatan Teknologi Informasi dan Komunikasi dalam Pembelajaran di SMA Muhammadiyah Tarakan. Jurnal Kebijakan Dan Pengembanganm Pendidikan, 2(2), 184-192

[13] Utami, I. S. (2016). Implementasi E-Learning untuk Meningkatkan Aktivitas Belajar Siswa. Jurnal Komputer Terapan, 2(2), 169-178

[14] Sofyana, L., \& Rozaq, A. (2019). Pembelajaran Daring Kombinasi Berbasis Whatsapp Pada Kelas Karyawan Prodi Teknik Informatika Universitas Pgri Madiun. Jurnal Nasional Pendidikan Teknik Informatika (JANAPATI), 8(1), 81. https://doi.org/10.23887/janapati.v8i1.17204

[15] Hameed, S., Badii, A. \& Cullen, A.J. (2008) .Effective ELearning Integration with Traditional Learning in a Blended Learning Environment. European and Mediterranean Conference on Information System. May 25-26.

[16] Akkoyunlu, B., \& Soylu, M. Y. (2008). A study of student's perceptions in a blended learning environment based on different learning styles.

[17] Sowiyah, S. (2020). Evaluation of Blended Learning-Based Education Implementation in FKIP Unila. Jurnal Pendidikan Progresif, 10(3), 429-439.

[18] Sadikin, A., \& Hamidah, A. (2020). Pembelajaran Daring di Tengah Wabah Covid-19. Biodik, 6(2), 109-119. https://doi.org/10.22437/bio.v6i2.9759

[19] Aliyyah, R. R., Puteri, F. A., \& Kurniawati, D. A. (2017). The Influence of Independence Learning To Natural Sciences Learning Outcomes. Jurnal Sosial Humaniora, 8(2), 126-143

[20] Sari, E. N., \& Zamroni, Z. (2019). The impact of independent learning on students' accounting learning outcomes at vocational high school. Jurnal Pendidikan Vokasi, 9(2), 141150. https://doi.org/10.21831/jpv.v9i2.24776

[21] Hidayat, D. R., Rohaya, A., Nadine, F., \& Ramadhan, H (2020). Kemandirian Belajar Peserta Didik Dalam Pembelajaran Daring Pada Masa Pandemi Covid -19. Perspektif Ilmu Pendidikan, 34(2), 147-154. https://doi.org/10.21009/pip.342.9

[22] Yulistia, A., Fitria, G \& Anggraini, F.G. (2021). LMS VCLASS Unila: Solusi untuk Meningkatkan Kemandirian Belajar dalam Pembelajaran Daring di Masa Pandemi. Seminar Nasional Pendidikan Ke-4 FKIP Universitas Lampung 2021. 153-159

[23] Hu, H \& Gramling, J. (2009). Learning Strategies for Success in a Web-Based Course: A Descriptive Exploration. The Quarterly Review of Distance Education. 10(2). 123-134
24] Kusni, M. (2010). Implementasi Sistem Pembelajaran Blended Learning pada Matakuliah AE3121 GetaranMekanik di Program Aeronotika dan Astonotika. Seminar Tahunan Teknik Mesin

[25] Fahmi, S., Syaiful, S., \& Soffi, W. P. (2017). Pendampingan Pembuatan E-Learning dengan Moodle yang dipadukan dengan Sofware Matematika Geogebra untuk Guru Matematika di SMP Muhammadiyah Se Kecamatan Godean Sleman Yogyakarta. Jurnal Aksiologi, 1(2), 135-141

[26] Haag, J. (2011). From elearning to mlearning: The effectiveness of mobile course delivery. In: Interservicel Industry Training, Simulation, and Education Conference (I/ITSEC). Orlando, Florida, U.S.A.

[27] Bétrancourt, M., \& Tversky, B. (2000). Effect of computer animation on userse performance: a review. Le Travail Humain, 63(4), 311-330.

[28] Indrayana, B., \& Sadikin, A. (2020). Penerapan E-Learning Di Era Revolusi Industri 4.0 Untuk Menekan Penyebaran. Indonesion Journal of Sport Science and Coaching, O(1), 4655.

[29] Yuberti. 2015. Online Group Discussion Pada Mata Kuliah Teknologi Pembelajaran Fisika. Jurnal Ilmiah Pendidikan Fisika "Al-Biruni". 4(2) halaman 145- 153.

[30] Lestari, A. S., \& Rijal Hamka, S. (2019). Analisis PIECES dalam Implementasi Kebijakan Learning di IAIN Kendari. MANAGERIA: Jurnal Manajemen Pendidikan Islam, 4(1), 103-125. https://doi.org/10.14421/manageria.2019.41-07

[31] Lopes, A.P. (2014). Learning Management Systems In Higher Education. Proceedings of EDULEARN14 Conference. 53605365.

[32] Astini, N. K. (2020). Tantangan Dan Peluang Pemanfaatan Teknologi Informasi Dalam Pembelajaran Online Masa Covid19. Cetta: Jurnal Ilmu Pendidikan, 3(2), 241-255. https://doi.org/10.37329/cetta.v3i2.452

[33] Phirangee, K (2016). Students' Perceptions of Learner-Learner Interactions that Weaken a Sense of Community in an Online Learning Environment. Online Learning. 20(4)

[34] Sara, K., witi, F.L \& Mude, A. (2020). Implementasi ELearning Berbasis Moodle di Masa Pandemi Covid-19. ALIGNMENT: Journal of Administration and Educational Management. 3(2). 